Sandler A.K., Drozd E.V. National University «Odessa Maritime Academy»

\title{
AUTOMATED LUBRICATION SYSTEM OF GUIDES TO MOVE HEAVY CARGOES
}

Recently the hydrostatic lifting systems designed for horizontal loading of heavy cargoes on vessel are becoming more widespread. This trend is due to a number of advantages of the lifting cargo guides over the traditional - they are of low cost, easy to use and could be easily mounted as systems for loads of different weights [1]. At the same time, application of the existing hydrostatic lifting systems showed their incomplete correspondence to the modern tasks of safe cargo operations [1, 2, 3]. To find ways to improve the cargo lifting guides performance the design solutions of their lubrication systems were analyzed $[3,4,5]$. The current lubrication system of the guides consists of triangular pockets on the guide's surface, oil-lines and a pump with electric drive [4].

Disadvantages of the device, which are caused by use of a pump with electric drive and direct supply of lubricant to the lubrication pockets:

excessive consumption of lubricant;

possibility of lifting the load bearing surface over the guide and creation of tipping moments for cargo;

dependence of the low-viscous oils from climatic conditions;

dependence of the system's working capacity on availability of electrical power.

To a lesser extent the operational and structural factors affect the characteristics of the guides' lubrication system, consisting of a group of triangular pockets on the guide's surface, oil-lines, throttles and electric power pump $[4,5,6]$. Disadvantages of the device, which are caused by use of the complex "electric power pump - throttle":

dependence of the low-viscous oils from climatic conditions;

dependence of the system's working capacity on availability of electrical power.

In the circumstances, development of the new design solution for lubrication system of guides, became appropriate. It was assumed that constructive implementation must provide:

possibility of using the consistent high viscosity lubricant with the necessary and sufficient consumption of these materials;

minimized impact of climatic factors in cargo operations;

independency of electric power; 
high level of fluid friction in the entire range of speeds and loads when moving cargo;

simplicity and reliability of design solutions of the known types of systems.

The scheme of guides' lubrication system is proposed for solution of the problem. The essence of the proposed design solution is explained by drawing (Fig. 1), which shows the guides' lubrication system to move heavy cargo, consisting of a guide 1 , pockets 2 , throttles 3 , oil-lines 4 , tank for lubricant cartridge 5, secondary hydraulic cylinder 6 with piston-rod 8 , primary hydraulic cylinders 7 , system converting the translational movement into the rotary 9 and a toothed rack 10 with a return spring 11 .

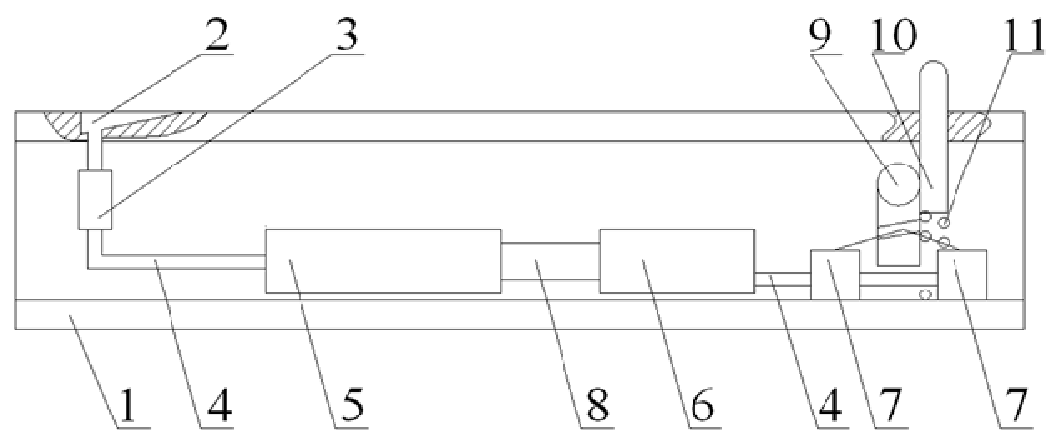

Fig. 1. Lubrication system of guides to move heavy cargo: 1 - consisting of a guide; 2 - pockets; 3 -throttles; 4 - oil-lines; 5 - tank for lubricant cartridge; 6 - secondary hydraulic cylinder; 7 - primary hydraulic cylinders; 8 - piston-rod; 9 - system converting the translational movement into the rotary; 10 - toothed rack; 11 -return spring

Starting up of the cargo transportation along the guides leads to contact of the cargo bearing with the spherical edge of the toothed rack. Under the cargo weight the toothed rack moves down in the guide bore. When moving the rail it turns on the system converting the translational movement into the rotary. In turn, the interaction of the system's drum surface with profiled cam groove with six primary hydraulic cylinders leads to increase of pressure in hydraulically bound secondary cylinder. At increasing pressure the piston-rod of the secondary hydraulic cylinder presses out the material of lubricant cartridge, in the relevant volume, through the throttles to the lubricant pockets. Thus the oil comes into the contact area of the cargo and the guide $[6,7]$. 
For the invention a combination of hydro-mechanical elements was used. In the static mode (before beginning of the cargo operation) the lubricant cartridge is placed to a tank and the tank is closed. Rod-piston of the secondary hydraulic cylinder is located in the secondary hydraulic cylinder. The toothed rack is raised to the top position by the return spring.

In dynamic mode (movement of cargoes) there is a contact of the cargo bearing with spherical edge of the toothed rack. Under the cargo weight the toothed rack moves down in the guide bore. When moving the rail it turns on the system converting the translational movement into the rotary. In turn, the interaction of the system's drum surface with profiled cam groove with six primary hydraulic cylinders leads to increase of pressure in hydraulically bound secondary cylinder. At increasing pressure the piston-rod of the secondary hydraulic cylinder presses out the material of lubricant cartridge, in the relevant volume, through the throttles to the lubricant pockets. The throttles, on which the pressure is decreased, are used to ensure that at different loads on the pockets, the pressure could not match, and was maximal only in the contact zone. Thus the oil comes into the contact area of the cargo and the guide.

After the cargo passes the contact area with the edge of the toothed rack, it rises upwards under the influence of the reverse spring, unloading valves of the "primary hydraulic cylinders - secondary hydraulic cylinder" subsystem, open, the pressure in the secondary hydraulic cylinder decreases and the rod piston returns to the hydraulic cylinder. Thus, there is a full cycle of the lubrication system.

The proposed design solution has a peculiar feature that its system includes a tank for lubricant cartridge, a power secondary hydraulic cylinder, rod-piston which, under the pressure created by six primary hydraulic cylinders that are driven by the government the system converting the translational movement into the rotary and the toothed rack, compresses lubricant cartridge and directs lubricant to the lubrication pockets.

Thus in the developed lubrication system the combination of hydromechanical elements provides:

creation of more adequate conditions for lubrication of guides;

possibility of lubrication process without additional power supply to the power equipment;

consideration and compensation of meteorological factors influence that affect cargo operations;

reduction of lubricant costs.

Use of the proposed device will allow the adequate and economic lubrication when moving heavy cargoes along the guides. 


\section{LITERATURE}

1. Подобед, В.А., Подобед, Р.В., Папуша, А.Н., Вульфович, Б.А. Транспортировка крупногабаритных особо тяжелых грузов морем // Вестник МГТУ. - 2014. - Том 17. - № 1. - С. 87 - 91.

2. Коробейников, А. Ф. Исследование гидростатических напрявляющих // Вестник Хакасского технического института - филиала КГТУ. - Абакан, 2006. - № 22. - С. 42 - 47.

3. Гаркунов, Д.Н. Триботехника (конструирование, изготовление и эксплуатация машин). - М.: ГРНТИ, 2002. - 426 с.

4. Бушуев, В.В. Гидростатическая смазка в станках. - М.: Машиностроение, 1989. - $176 \mathrm{c}$.

5. Гидродинамические направляющие [Электронный ресурс]. Режим доступа: http://www.linear.com.ua/catalog/hiwin-linear-motion.pdf (дата обращения 17.03.2017).

6. Фещенко, В.Н. Справочник конструктора. Книга 2. Проектирование машин и их деталей. - М.: Инфра-Инженерия, 2016. - 400 с.

7. А.c. 982867 СССР, М.Кл ${ }^{3}$ В 23 Q 1/02. Гидростатические направляющие металлорежущего станка /С.Н. Аграновский, Г.В. Гаврилова, Б.С. Шейнин; заявитель и патентообладатель Особое конструкторское бюро станкостроения. - № 3297247/25-08; заявл. 05.06.81; опубл. 23.12.82. Бюл. № 47. -2 с. 